\title{
Sexuality experiences of hysterectomized women
}

\author{
Experiências de mulheres histerectomizadas acerca da sexualidade \\ Experiencias de mujeres histerectomizadas acerca de la sexualidad
}

\section{Alessandra Schmidt ${ }^{1}$ Graciela Dutra Sehnem² Leticia Silveira Cardoso ${ }^{1}$ Jacqueline Silveira de Quadros ${ }^{2}$ if Aline Cammarano Ribeiro ${ }^{2}$ (I) \\ Eliane Tatsch Neves ${ }^{2}$ (iD)}

1. Universidade Federal do Pampa.

Uruguaiana, RS, Brasil.

2. Universidade Federal de Santa Maria. Santa Maria, RS, Brasil.
Corresponding author:

Graciela Dutra Sehnem.

E-mail: graci_dutra@yahoo.com.br.

Submitted on $02 / 27 / 2019$

Accepted on 05/24/2019.

DOI: 10.1590/2177-9465-EAN-2019-0065

\begin{abstract}
Objective: To know the sexuality experiences of hysterectomized women. Method: Qualitative study carried out in Family Health Strategies with 19 hysterectomized women. A semi-structured interview was conducted, combined with the Creativity and Sensitivity Technique called Speaker Map, after approval by the Ethics Committee from January to February 2018. Data were analyzed according to analysis of the thematic content. Results: The participants had different sexuality experiences after the hysterectomy. The procedure was associated with restoration of health, resuming sexual activity, and changes in relationships. It was also related to the onset of dyspareunia and decrease in libido. Conclusion and implications for practice: The changes experienced after surgery led women to build new meanings for sexuality and their relationships. The surgery shows concrete results, such as decreased or increased pain in sexual practice, and subjective results, such as the feeling of freedom and the impact on female identity. These results may contribute to direct educational strategies to approach sexuality with each woman who undergoes hysterectomy.
\end{abstract}

Keywords: Sexuality; Hysterectomy; Femininity.

\section{Resumo}

Objetivo: Conhecer as experiências de mulheres histerectomizadas acerca da sexualidade. Método: Estudo qualitativo realizado em unidades da Estratégia Saúde da Família com 19 mulheres histerectomizadas. Utilizou-se entrevista semiestruturada combinada com a Técnica de Criatividade e Sensibilidade denominada Mapa Falante, após a aprovação do Comitê de Ética, no período de janeiro e fevereiro de 2018. Os dados foram analisados segundo análise de conteúdo temática. Resultados: As mulheres sentiram-se diferentes para vivenciar a sexualidade após a histerectomia. Este procedimento foi associado ao restabelecimento da saúde, à retomada da vida sexual e à mudança nos relacionamentos. Também esteve relacionado ao surgimento de dispareunia e à diminuição da libido. Conclusão e implicações para a prática: As mudanças vivenciadas a partir da cirurgia fizeram as mulheres construírem novos significados acerca da sexualidade e dos seus relacionamentos. A cirurgia desdobrou-se em questões concretas, como a diminuição ou aumento da dor nas relações sexuais, e em questões subjetivas como a sensação de liberdade e o impacto na identidade feminina. Esses resultados podem contribuir para direcionar estratégias educativas para abordar a sexualidade com cada mulher que vivencia a histerectomia.

Palavras-chave: Sexualidade; Histerectomia; Feminilidade.

\section{Resumen}

Objetivo: Conocer las vivencias de mujeres histerectomizadas acerca de la sexualidad. Método: Estudio cualitativo realizado en Estrategias Salud de la Familia con 19 mujeres histerectomizadas. Se utilizó la entrevista semiestructurada, combinada con la Técnica de Creatividad y Sensibilidad denominada Mapa Hablante, después de la aprobación del Comité de Ética, en el período de enero y febrero de 2018. Los datos fueron analizados según el análisis de contenido temático. Resultados: Las mujeres se sintieron diferentes para vivir la sexualidad después de la histerectomía. Este procedimiento se asoció al restablecimiento de la salud, la reanudación de la vida sexual y el cambio en las relaciones. También, estuvo relacionado al surgimiento de dispareunía y a la disminución de la libido. Conclusiones e implicaciones para la práctica: Los cambios vivenciados a partir de la cirugía hicieron que las mujeres construyeran nuevos significados acerca de la sexualidad y sus relaciones. La cirugía se desdobló en cuestiones concretas, como la disminución o aumento del dolor en las relaciones sexuales y, en cuestiones subjetivas como la sensación de libertad y el impacto en la identidad femenina. Estos resultados pueden contribuir para el direccionamiento de estrategias educativas para abordar la sexualidad con cada mujer que vivencia la histerectomía.

Palabras clave: Sexualidad; Histerectomía; Feminidad. 


\section{INTRODUCTION}

Hysterectomy is the total removal of the uterus, when the uterus and cervix are removed, or partial removal, in which the cervix is kept, being considered the second most common gynecological surgery in the world among women in reproductive age. ${ }^{1,2}$ With respect to Brazil, about 83 million hysterectomies were performed in 2014 and about 34 million of them were oncological surgeries. ${ }^{3}$

The main indications for this type of surgery include benign gynecological diseases, such as abnormal uterine bleeding and symptomatic uterine leiomyoma. ${ }^{2}$ It can be performed vaginally, through abdominal incision, or by laparoscopic route, the latter in which the organ is removed through small incisions, which is a minimally invasive technique. ${ }^{1}$

Removal of the uterus can be a difficult process to be faced by women, especially as it involves emotional, psychological, and cultural factors. The uterus, in addition to the biological function, has symbolic values related to femininity. ${ }^{2,4}$ There are sensations and characteristics related to body perception that are common to women after surgery, among them, feeling awkward and change in the body image, the feeling of mutilation of their body, emptiness, and feeling different from other women. ${ }^{4}$

Hysterectomy can have positive or negative implications in the sexuality experience of these women, which may reflect on their self-image, marital and social relationship, or even revealed through depressive symptoms. ${ }^{5,6}$ Sexuality is influenced by the socio-cultural construction, and is interrelated in gestures, words behaviors, looks, attitudes, and in the silence of each one as well It covers matters such as gender, identity, and sexual orientation, eroticism, pleasure, intimacy, and reproduction. ${ }^{7}$

Therefore, these women need to receive comprehensive health care, in which the impacts related to the hysterectomy are addressed, in order to clarify doubts and expectations regarding the surgery, as well as their possible interference with the quality of life. The nurse should welcome these women and establish a bond using sensitive and qualified listening in order to promote knowledge about their bodies, to identify the values attributed to the uterus, and how sexuality is experienced before and after the gynecological surgery, in order to support them in this process. ${ }^{6,8}$

In an attempt to identify the scientific production about the sexuality of hysterectomized women, there was a search in the national and international literature. The papers available in the last five years have focused on matters such as the effects of hormone replacement therapy on the sexual function of women with gynecological surgery; the influence of different hysterectomy techniques on sexual function; the meaning for women of removing their uterus; and quality of life after the procedure. Thus, there is a need for greater investments in research on the sexuality experiences of women who underwent hysterectomy in the area of Nursing and health sciences.

The study is based on the following research question: What are the experiences of hysterectomized women related to sexuality? In order to answer to this questioning, the objective was to know the experiences of hysterectomized women related to sexuality.

\section{METHOD}

A descriptive and exploratory qualitative study. The research scenario was five Family Health Strategy (ESF _ "Estratégia Saúde da Família", in Portuguese language) located in the urban area of a city on the western border of Rio Grande do Sul. Choosing this scenario is justified by the characterization of the ESF as the entry point for women in the service network of the Unified Health System (SUS - "Sistema Único de Saúde", in Portuguese language), as well as the importance of these spaces of care for nursing practices aimed at health education actions and health promotion of hysterectomized women.

19 women participated in this study, which was based on data saturation, in which the researcher identified that no new information was added and was able to understand the internal logic of the public. ${ }^{9}$ Females older than 18 years of age who underwent hysterectomy for more than six months were used as inclusion criteria to participate in the study in order to enable a longer experience of their sexuality after surgery. Exclusion criteria were: women undergoing chemotherapy, considering that this process may change their health status, and consequently, their perceptions about sexuality.

The selection was intentional, considering that the participants were indicated by the nurses of the health units. Those who met the criteria mentioned above received an invitation at their home through the Community Health Workers (CHW). After this initial contact, the $\mathrm{CHW}$ scheduled the location, date, and time according to the participants' availability for the interview. The interview took place mostly in their households, except for three conducted at the health service, both individually to keep the information confidential.

For collection of information, the semi-structured interview ${ }^{9}$ was combined with the Creativity and Sensitivity Technique (TCS - "Técnica de Criatividade e Sensibilidade", in Portuguese language) ${ }^{10}$ referred to as Speaker Map (MF - "Mapa Falante", in Portuguese language). The TCS is considered an alternative form of data collection in research in the nursing area and instigates the participants' subjectivity. ${ }^{10}$ The collection took place in the first half of 2018, the interviews were conducted by the responsible researcher and lasted about one hour. The interviews were recorded, with the women's authorization, in an audio device and later transcribed in full for analysis and interpretation.

First the objectives of the research were presented, as well as the ethical principles that would guide the interview. Later the semi-structured interview was conducted with the following questions: How do you feel and perceive yourself after surgery? Do you feel any changes in your self-image after surgery? Which ones? Can you name some positive effect of hysterectomy on your affective and sexual life? Can you name some negative 
effect of hysterectomy on your affective and sexual life? What do you and your partner talk about this topic? Possible changes in sexuality were discussed at any time by the nurse? What do you think the nurse should talk about the sexuality of women who undergo a hysterectomy? Next the speaker map was created guided by the following question: How do you perceive yourself after the hysterectomy? At this moment, the participants presented the drawing to the researcher and explained their meaning.

The material was analyzed through Minayo's thematic analysis, characterized by three stages. ${ }^{9}$ In the pre-analysis, the first exploratory level, the profile was established, comprising the history and the characterization of the researched group. In addition, the type of categorization and the coding modality were outlined. The second stage, exploration of the material, was characterized by a classificatory operation to understand the focus of the text. This was the moment when the data was organized into thematic categories, reducing the text to meaningful expressions or words. The third stage was the treatment of the results and their interpretation. In this stage, inferences and interpretations were made, correlating them with the initial theoretical framework, but also enabling new theoretical and interpretative dimensions, suggested from the reading of the collected material.

The research followed the precepts of Resolution no. 466/12 of the National Health Council of the Ministry of Health, with approval of the Ethics Committee, under the CAAE protocol No. 80627317.7.0000.5323 and opinion No. 2,437,609. To preserve the anonymity of the interviewees, the participants were identified using the alphanumeric system using the codename $\mathrm{W}$, related to women, followed by an Arabic numeration according to the order of interviews.

\section{RESULTS}

19 women were interviewed in the age group from 33 to 80 years of age. Most of them were aged between 43 and 58 years. As for marital status, 13 were married and/or had a domestic partnership, four were widows, and two were single. They stated they had one to six children, with the average between two and three children; it is noteworthy that two did not have children.

In terms of education, nine completed high school, nine did not complete middle school, and one did not complete the higher education. With respect to the profession, two were retired, two were housewives, and the others were retail or domestic workers. The reason for the hysterectomy for 13 of the study participants was the presence of uterine fibroids; two were operated due to ovarian cyst, one due to low-grade neoplasia, one due to spongy carcinoma, one due to endometriosis, and one due to bladder prolapse.

The analysis of information provided by the participants showed three thematic categories, namely: Positive experiences related to sexuality; Difficulties in experiencing sexuality; and Health care of hysterectomized women.

\section{POSITIVE EXPERIENCES RELATED TO SEXUALITY}

Some participants in this study reported improvement in sexuality during intercourse after the hysterectomy. For these women, the surgery freed them from symptoms mostly caused by uterine fibroids (benign tumors), which caused bleedings, in addition to dyspareunia. In this sense, it can be noticed that the removal of the uterus was intended to restore health, as well as to resume the sexual life, previously compromised. These issues are illustrated in the speaking map in figures 1 and 2.

Figure 1. Speaker map produced by participant W11.

Source: Investigation data.

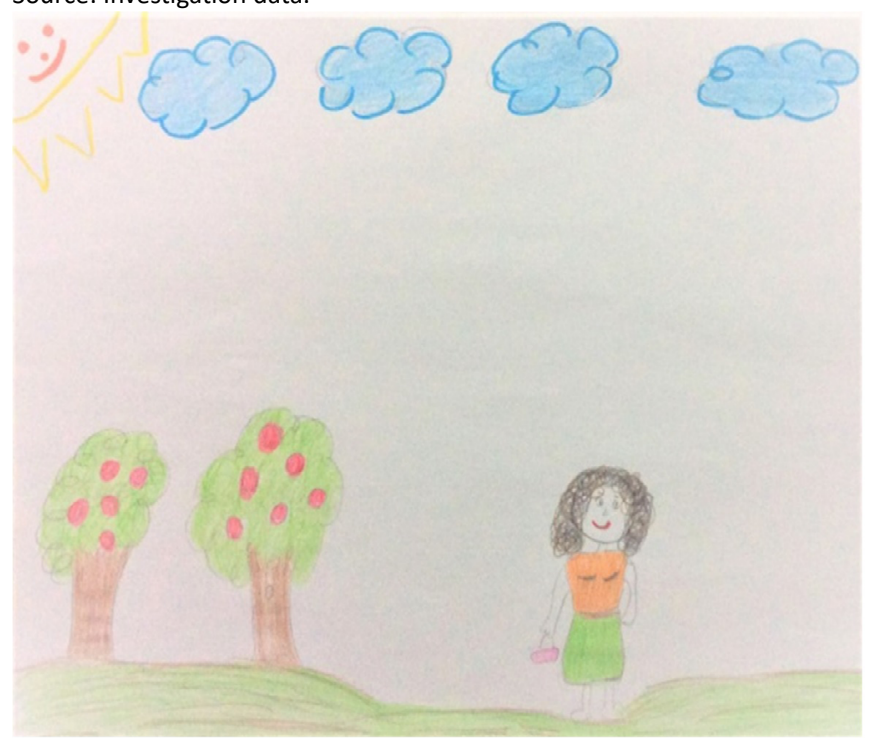

Figure 2. Speaker map produced by participant W18. Source: Investigation data.

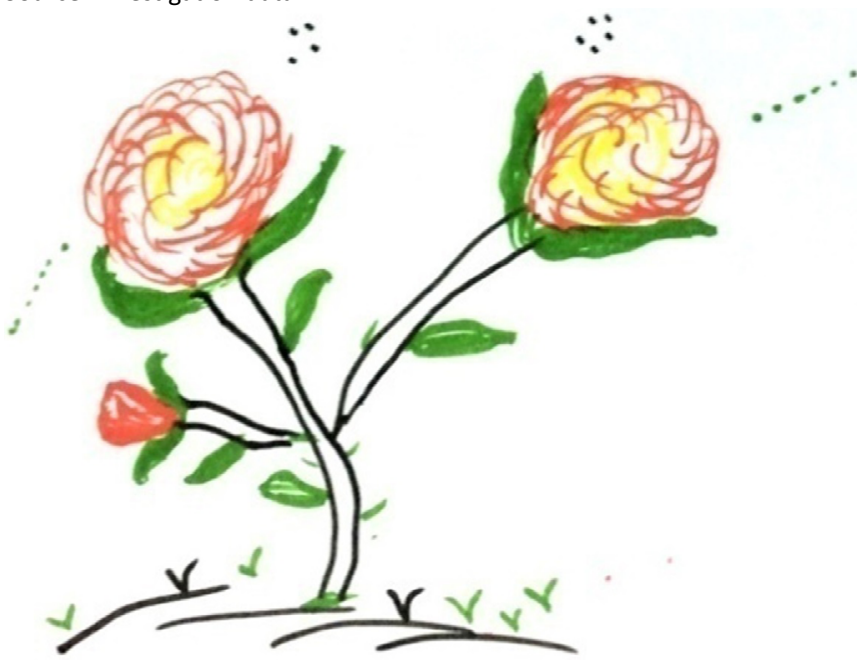


I couldn't wear white pants, I don't feel any pain today, I am not angry anymore, I had a chronic anger, all that is gone. [...] if I want to have sex anytime I do, I don't need to get desperate or curse because of pain, this is all a good thing (W10).

Our freedom during sex is very good. To this day we have used condoms, because we have always used them. [...] sexual desire has nothing to do with the surgery itself, it continued the same (W4).

I drawn myself happy, because I don't suffer any more from bleedings, and walking around because it is something I could not do, I didn't want to leave the house for being afraid to get my pants dirty (SPEAKER MAP, W11).

I feel like a rose because the rose is so beautiful and sturdy. I am a real person with normal problems, but I still can feel beautiful (SPEAKER MAP, W18).

It is possible to note that the partners supported the women in this delicate moment, which was important for them to deal with this situation. These matters are highlighted in the following reports and on the speaking map (Figure 3):

Figure 3. Speaker map produced by participant W3.

Source: Investigation data.

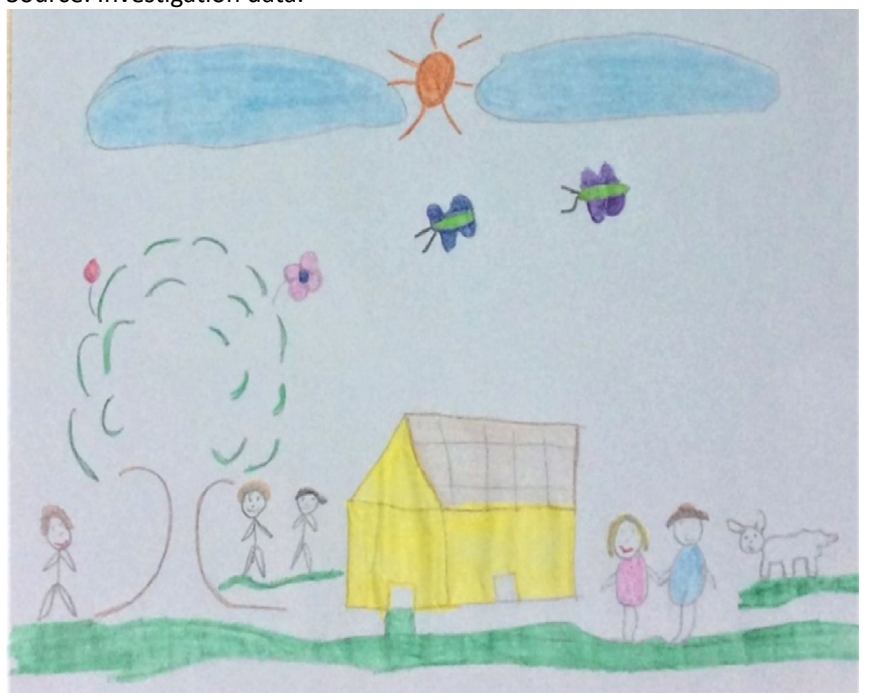

I feel good [...] today I am a different woman, I was born again. [...]my husband said: if it was better for me, I had to do the surgery, he even went to the doctor with me to understand that I would not be "cold"; he understood me and gave me strength (W19).

My husband was a great partner, I was suffering from that situation and he was too, but he did not abandon me in any moment (W5).
My husband said that marriage is not just sex, marriage is a partnership. We have been together for 30 years, it is not because of sex that we will stop being a family. [...] he (husband) told me: let's do the surgery, you'll be fine and we'll solve any problems there might be (W10).

I drew my house happy, together with my son, me, and my husband, my dog, a tree that I really like, the sky, the sun, and a few butterflies [...] in short, I just got happy after the surgery (SPEAKER MAP, W3).

Most of the interviewees already had children, hence, for them, the uterus had already played its role as a reproductive organ. At this moment, the uterus was perceived as a problem and the solution was to remove it, which made them feel somewhat relieved, too, about an unwanted pregnancy, providing later freedom in the married life.

The relationship with my husband, in my opinion, has improved, to have sex without getting pregnant, not having to take contraceptives, it is a type of freedom. [...] he supported me to do the surgery, he helped me in everything, he knew about the decision to not have more children, I had already done the tubal ligation, so for us it was very good (W11).

The upside is that you no longer have the risk of getting pregnant and when I have sexual intercourse, for sexual desire, I have more orgasms than usually. My husband was very afraid, because of this myth, he thought it wouldn't be the same, but he said: I will take care of you, don't worry (W18).

\section{DIFFICULTIES IN EXPERIENCING SEXUALITY}

Some participants in the study reported difficulties in experiencing sexuality after hysterectomy, associated with pain during sex and decreased sexual desire, as illustrated on the speaking map (Figure 4). They also reported feeling weird in the penetration during intercourse, a situation that may be related to the lack of or decrease in vaginal lubrication and to the modified self-image perception after surgery.

[...] I usually don't have intercourse. This other partner I have does not say anything negative or positive in our sex life. I don't even want to have sex. After a few years I have a lot of pain, we are not in the same page, I feel "cold" (W1).

These pains I felt after the surgery to have sex, I do not know what they may be (SPEAKER MAP, W1).

My body has changed, it is different in the penetration from when you have cervix and uterus. You feel the difference and you know it is different (W2). 
Figure 4. Speaker map produced by participant W1.

Source: Investigation data.

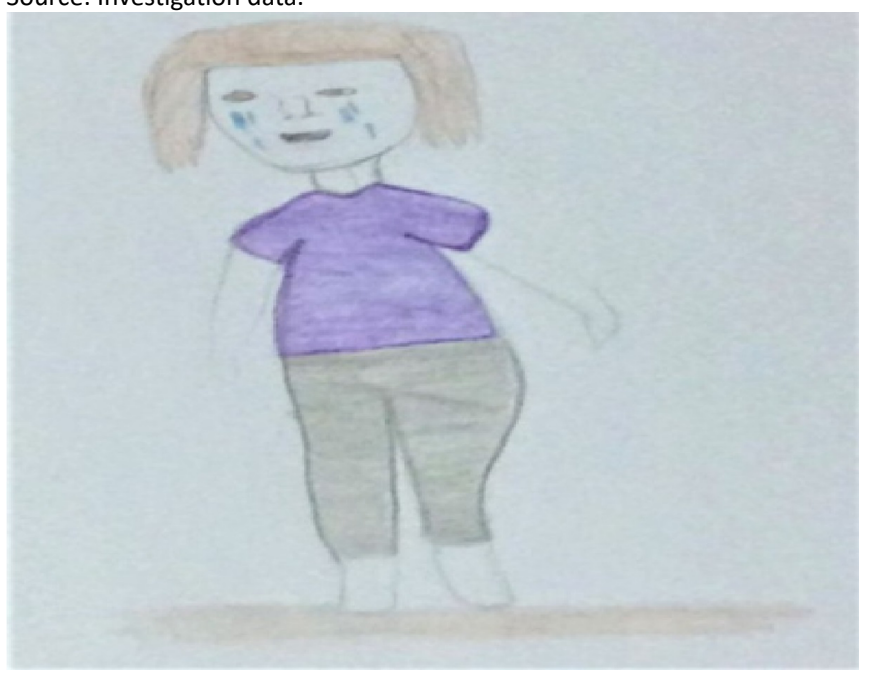

Now I struggle to have sex, because sex before the surgery was actually to have a child. Over time, I changed the way I think, I went to the psychologist, I had treatment for a year [...] but the downside was the difficulty in having sex, I got very dry, without lubrication, the doctor said that this is totally normal. Another change is also in sexual desire, there was a decrease in sexual desire, I don't know if it is because of surgery or depression (W12).

I thought, I won't be able to get pregnant any more, I had already lost two children because of the bleeding, I was sick every month, all year long [...] so I decided to have the surgery. I feel weird during sexual intercourse for removing such an important organ of my body (W16).

Women who underwent hysterectomy may suffer uncomfortable physical changes that interfere with quality of life. In this context, some participants brought up issues such as urinary incontinence and weight change after surgery. This can be evidenced in the following report and on the speaking map (Figure 5):

After I had my uterus removed, it looks like I will have to urinate more, I can't hold the urine when I cough or need to do a physical effort. To be quite honest, this has cooled down, the sexual desire has decreased a lot, I don't know why, but it has (W16).

After the surgery I felt I put on some weight, my body shape changed, but this was the only change I noticed (SPEAKER MAP, W15).
Figure 5. Speaker map produced by participant W15.

Source: Investigation data.

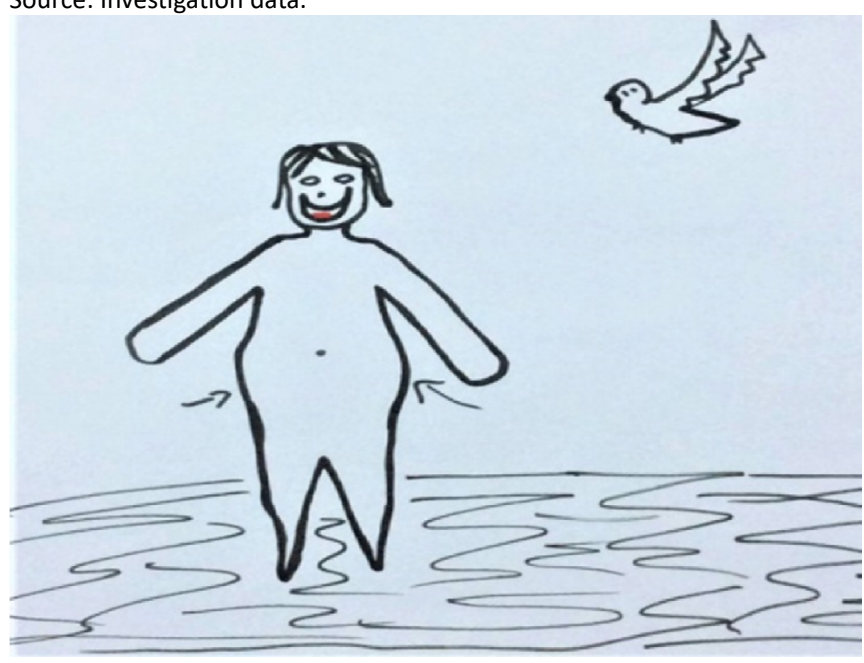

\section{HEALTH CARE OF HYSTERECTOMIZED WOMEN}

The professional nurses, especially those who work in primary health care, are responsible for providing guidance on this surgery, explaining the possible changes that may happen in the woman's body and that these changes may adversely influence her relationships with her partners. However, the reality found from the reports of the participants shows that this professional does not carry out this educational process. This matter is sometimes present in medical practice and associated with merely biological questions.

I talked to the doctor and he said it was up to me, the head was important, not the sexual part, because there are women who are very influential. He said that this will not change the sex at all, I will continue the same way, if I didn't have the desire before, it would continue the same (W5).

The nurse didn't inform me. Only the doctor explained what he had done in the surgery. (W7).

No one said anything before the surgery, only after. The doctor asked me if I had a boyfriend, maybe because I couldn't have sex anymore (W8).

The person who talked to me was the doctor herself, not the nurse; she did not explain to me about the surgery, she actually sent me straight to the doctor, and the doctor was the one who explained to me that it was not a simple surgery, but everything would be alright because I already have children, it was not for me to worry (W15). 
I did not receive any guidance in this regard [...] I would ask things straight to the doctor, I felt no shame or fear to ask him: doctor will this happen to me? How will I be? How will I feel? How will the sexual intercourse be? Then he informed me about these questions, not the nurses (W18).

Due to the lack or absence of guidance, by the nurse or the doctor, women seek information from other sources, such as the opinion of other women who have already undergone the same procedure, as well as interviews or watching news on the television, and one of the most used media is currently the internet.

\begin{abstract}
At any time this was mentioned, I discovered that it could affect sexuality, the sexual desire could change, but that was it, I read about it, no one told me anything (W9).

I remember the doctor only said that it would stop bleeding, that I wouldn't have my period anymore, but I mean, only what I studied and browsed, not that anybody has spoken to me (W11).

I always tried to inform myself and to investigate [...] what I would feel, I sought testimonies from other women, the taboo that women were cold and no longer good for anything, so I studied this deeply and it didn't shake me (W17).
\end{abstract}

Given the lack of information and broader guidelines regarding hysterectomy, the study participants report their expectations for improved care and assistance for women undergoing gynecological surgery. For this, they emphasized the importance of receiving guidelines about the surgery during the appointment with the primary care nurse. They also admitted that they needed a hospital-based and comprehensive follow-up, reinforcing the emotional issue. They recommended that professionals approach sexual matters and the need for psychological counseling.

I think that from the moment the woman learns that she needs surgery, she needs to talk to the nurse or the doctor about what may or may not happen in the sex life [...] in some cases, people get depressed and I think people should see a psychologist during this period(W9).

I think they should try to comfort them, because there are women who don't seek information, so when someone says they have to undergo surgery, they already have a thousand things going through their heads. I think there should exist a trained person to inform, to follow up, maybe to talk to our families, a nurse could come along to inform and clarify the doubts (W17).

I think that before surgery you need a lot of advice from the nurse, I think sex is a thing that the couple worries about, so much so that nowadays I tell my friends that everything is normal [...] after surgery women need the see a psychologist because they won't get pregnant any more (W18).

\section{DISCUSSION}

Sexuality should be understood as a multifaceted concept, inter-related in social and cultural aspects experienced by each individual throughout their trajectory and is revealed through looks, caresses, expressions, attitudes, posture, and the human behavior itself. Sex refers to biological characteristics that distinguish men from women; on the other hand, sexuality goes beyond the sexual act itself, such as sexual orientation, intimacy, pleasure, reproduction, and other feelings involved. ${ }^{7}$

The study participants' understanding of the concept of sexuality was strongly associated with the sexual act, emerging from a cultural understanding about the subject and a narrow view regarding its broad definition. ${ }^{11}$ The effects of hysterectomy on sexuality are complex and derive from several factors such as physical, social, psychological, religious, cultural, and educational factors, changing the woman's perspective of herself and her body, in which the uterus has a strong representation of what is understood as feminine and fertile. The need for hysterectomy can cause fear and doubt, especially when sexuality is strongly associated with genitality. ${ }^{12}$

Some of the participants revealed in their reports an improvement during the sexual act after the hysterectomy. This fact was also verified in a narrative review, which showed improvement in most sexual disorders after hysterectomy caused be benign uterine diseases, as well as in the sexual performance of women with active sex life before the procedure. ${ }^{13}$

According to a mixed approach study carried out in a specialized service, female sexual performance and satisfaction did not change after hysterectomy. ${ }^{14}$ It also emphasizes that the impact on the quality of sex life depends on several aspects that surround sexuality as it is a complex and multifactorial area, which changes over time and with the group women live with, in addition to internal factors such as affectivity, cognition, and emotion.

The results of a survey conducted in Jordan with a sample of 124 women who had benign disorders and underwent hysterectomy indicated that their greatest concern was about sexual performance..$^{15}$ Therefore, the authors found that there was a significant improvement in sexual function and in the health of women undergoing this procedure. Hysterectomy eliminates problems of bleeding, pain in sexual intercourse, and issues related to contraception, which may contribute to a better quality of life and sexual function. ${ }^{16}$

Regarding the women' reaction to the loss of the uterus, this study reveals moments of distress and/or anxiety. They depend on the intensity of the symptoms, the woman' emotional state, and the quality of the relationship with the partner. ${ }^{17}$ Surveys conducted with women who underwent hysterectomy showed that the partners showed support during the procedure, which conveys safety to the partner and proved to be a positive 
experience that facilitated the experience of gynecological surgery. ${ }^{18,19}$

This opportunity, through gynecological surgery, to reevaluate feelings and attitudes within the marital relationship may be associated with the quality of the couple's relationship. ${ }^{19}$ In addition, this reiterates that the value that the organ removed has for women is historically based on social and cultural constructions, which delimited roles and obligations inherent to each sex. ${ }^{4}$ Thus, female nature has as its main basis biological facts that occur in the woman's body, such as the ability to generate, give birth, and breastfeed, as well as period. ${ }^{4}$ Accordingly, it is understood that, in order for women to overcome attributes that associate women's sexuality only with being a mother and reproduction, the partners' support was important in this study.

Regarding the difficulties for experiencing sexuality after the hysterectomy, some participants associated it with pain during the sexual act and decreased sexual desire. The study indicates that there was a decrease in sexual excitement and in the frequency of sexual intercourses after the hysterectomy, and the symptoms of depression after this procedure had an adversely effect on sexual performance. In addition, it revealed the presence of dyspareunia and decreased vaginal lubrication. ${ }^{13}$

These data were also evidenced in a literature review, which revealed that approximately 10 to $20 \%$ of the women who underwent a hysterectomy experience some change in sexual function, such as dyspareunia, change in orgasm and/or less sex. Those women who undergo surgery for gynecological malignancy have demonstrated deterioration in sexual function related to decreased sexual desire and inadequate lubrication. ${ }^{16}$ A research carried out in China with 125 women submitted to radical hysterectomy showed that after the procedure there was a high incidence of sexual dysfunction, which was stabilized after two years..$^{20}$ Pursuant to this data, another study also stated that there is a comparable improvement in sexual function after a long period of the procedure. ${ }^{21}$

Hysterectomy can be performed simultaneously with bilateral oophorectomy. ${ }^{16}$ Removal of the ovaries can cause long- term adverse effects on sexual function and health, as they are responsible for the release of hormones, such as estrogen and androgen, which lead to more severe climacteric symptoms and sexual changes. ${ }^{16}$ One of the alternatives would be hormone replacement in order to reduce complaints of inadequate lubrication and dyspareunia; however, this may not be a satisfactory choice when there is a concomitant premenopausal. ${ }^{16}$

As for the understanding of the need to have a uterus playing its role of generating life, this idea remains and is clearly imbricated in cultural aspects. Regarding this topic, a study carried out in Norway corroborates the opinion of some participants in the current research. Eight women, aged between 25 and 43, were interviewed, with emphasis on their experiences related to hysterectomy and the interaction that this event can evoke. Participants emphasized the importance of having a biological child, and removal of the uterus affected this possibility. ${ }^{22}$

Regarding the main morbidities after a radical hysterectomy, it is highlighted the dysfunctions that affect the bladder, both by the proximity of the uterus and the urinary tract, and by disturbing structures such as autonomic innervations and blood supply after removal of the cervix. ${ }^{23}$ The study showed association between hysterectomy and changes in the urinary, anorectal, and genital systems. ${ }^{24}$ The main dysfunctions that emerged as a result of the surgery were genital prolapse, innervation of the pelvic viscera, and changes in blood supply, which could lead to stress urinary incontinence.

These changes in the body happen naturally throughout life, but when subjected to hysterectomy surgery, it may reflect mainly in negative effects on the physical image, with difficulties in accepting this new body reality, ${ }^{4}$ as experienced by some participants in this study. It is considered that the understanding and the experience that the woman has about her sexuality and femininity before the surgery can somehow reflect on the marital relationship and the quality of life itself.

Regarding the health care of hysterectomized women, sexuality is a subject that remains unspoken, sometimes ignored and considered by several professionals as a delicate subject, belonging to the private sphere, and this situation leads women to feel uncomfortable talking about it. ${ }^{25}$ Unfortunately, most professionals do not encourage a discussion about this subject before the procedure, nor even evaluate the woman's perception of her self-image, ${ }^{26}$ that is, sexuality is not even seen or reflected by professionals as a possibility to act or provide care for women. Moreover, the existence of cultural, personal barriers, low levels of education, and the very shyness of professionals and women interfere with the effectiveness of care. ${ }^{13}$

Participants in another survey revealed that the search for information on the subject occurred through conversations with other women who had similar conditions. ${ }^{17}$ However, after the surgery, the same doubts remained and/or new questions were raised regarding the procedure, and information received during the preoperative period was unsatisfactory. In this sense, there are questions regarding the recovery time and return to sexual life, the care with the wound, and the need for annual cervical cancer examination. ${ }^{12}$

In this perspective, bonding is an important factor, for example, in primary care services, so that the woman feels comfortable talking about sexuality with the health care practitioner, especially when faced with the need for gynecological surgery. Through the bond, the woman and her partner can clarify doubts not only about surgery, but also about issues that permeate motherhood and femininity, demystifying possible myths or beliefs about sexuality. ${ }^{12}$ For this, the nurse needs to know the individual and sociocultural factors that surround the life of this woman, so that the understanding on issues related to surgery and sexuality can be understood in a singular way. ${ }^{4}$ 
Therefore, it is necessary to include in the educational process of hysterectomy surgery, not only the woman, but also her partner, due to the emotional support he provides, their understanding about the importance of the procedure for the health of the woman, as well as suppressing existing fears and ruling out feelings of abandonment. It is essential that the couple receives psychological support in the pre and postoperative period so that they can adapt to the new reality and are able to deal with any sexual complications, in order to improve the couple' sexual functioning according to their needs. ${ }^{13}$

Women who undergo hysterectomy have female needs, which include a support network that integrates the family, the society, and healthcare practitioners. It is essential that services on different levels with a multidisciplinary approach are prepared to meet the demands of these women who experience different confrontations, since, in most cases, they have concerns related to physical and emotional issues. ${ }^{27}$

\section{CONCLUSION}

The study showed that after the hysterectomy, women had reflected on the changes influenced by the surgery in the experience of sexuality and their relationships. Surgery resulted on concrete issues, such as decreased or increased pain in sexual intercourse, and subjective issues, such as the feeling of freedom and the impact on female identity.

Some participants had an improvement in quality of life after surgery and denied changes that interfered with sexual intercourse. One of the reasons that influenced women to choose for the hysterectomy was the support they received from their partner, precisely because of the fear of sexual dysfunctions after the procedure. On the other hand, some participants associated the physical loss of the uterus with the construction of the selfimage. They perceived a different body, a body marked by loss, reflecting on femininity and reducing sexual desire.

The role of nurses in primary health care, in the care of women in the pre and post-hysterectomy period, has proved to be fragile, especially regarding the approach to sexuality and surgery-specific orientations. With the purpose of avoiding aggravations and improving women's quality of life, it is essential that the nurses follow up these women in the context of health care and meet their individual needs, especially when the process involves such individual and important implications. In addition, some women requested psychological support.

The research limitations are related to the difficulty in approaching the subject, since, discussing the topic can generate shyness and insecurity. It is important to reinforce the need to carry out studies about the multidisciplinary care of women who undergo gynecological surgery.

\section{REFERENCES}

1. Doğanay M, Kokanalı D, Kokanalı MK, Cavkaytar S, Aksakal OS. Comparison of female sexual function in women who underwent abdominal or vaginal hysterectomy with or without bilateral salpingooophorectomy. J Gynecol Obstet Hum Reprod [Internet]. 2019 jan; [cited 2019 feb 26]; 48(1):29-31. Available from: https://www.ncbi.nlm.nih.gov/ pubmed/30445203http://dx.doi.org/10.1016/j.jogoh.2018.11.004

2. Skorupska KA, Miotła P, Kubik-Komar A, Rechberger E, AdamiakGodlewska A, Rechberger T. Are there any differences in quality of life and sexual functions after various types of hysterectomy - does prophylactic salpingectomy matter?. Ginekol Pol [Internet]. 2016; [cited 2018 nov 24]; 87(1):26-31. Available from: https://www.ncbi.nlm.nih. gov/pubmed/27306465http://dx.doi.org/10.17772/gp/60554

3. Freitas CB, Gomes NP, Campos LM, Estrela FM, Cordeiro KC, Moreira dos Santos R. Complicações pós-cirúrgicas da histerectomia: revisão integrativa. Rev Baiana Enferm [Internet]. 2016 jan; [cited 2018 dec 16]; 30(2):1-11. Available from: https://portalseer.ufba.br/index.php/ enfermagem/article/view/15660/pdf_50http://dx.doi.org/10.18471/rbe. v30i2.15660

4. Silva CMC, Vargens OMC. A mulher que vivencia as cirurgias ginecológicas: enfrentando as mudanças impostas pelas cirurgias. Rev Latino-Am Enferm [Internet]. 2016; [cited 2018 nov 19]; 24(e2780):18. Available from: http://www.redalyc.org/pdf/2814/281449727020. pdfhttp://dx.doi.org/10.1590/1518-8345.1081.2780

5. Araújo CRG, Rosas AMMTF, Menezes HF, Pinto ACS, Rodrigues BMRD. O Fenômeno Vivido por Mulheres na Consulta de Enfermagem na Braquiterapia Ginecológica. Texto Contexto Enferm [Internet]. 2017; [cited 2019 jan 13]; 26(2):1-10. Available from: http://www. scielo.br/scielo.php?pid=S0104-07072017000200335\&script=sci arttext\&tlng=pthttp://dx.doi.org/10.1590/0104-07072017000140016

6. Rocha RC, Bezerra MA, Rocha JC, Rocha NM, Gonçalves CB, Cardoso AR. Processo de enfermagem aplicado a paciente submetida à histerectomia: relato de experiência. Rev Enferm UFPI [Internet]. 2015 jul/sep; [cited 2018 dec 06]; 4(3):86-90. Available from: http://bases. bireme.br/cgi-bin/wxislind.exe/iah/online/? IsisScript=iah/iah.xis\&src= google\&base $=$ BDENF\&lang=p\&nextAction=Ink\&exprSearch $=31290$ \&indexSearch=ID. https://doi.org/10.26694/reufpi.v4i3.1879

7. Sehnem GD, Pedro EN, Budó MD, Silva FM, Ressel LB. A construção da sexualidade de estudantes de enfermagem e suas percepções acerca da temática. Cienc Enferm [Internet]. 2014; [cited 2018 nov 07]; 20(1):111-21. Available from: http://www.redalyc.org/ pdf/3704/370441815010.pdf

8. Schmalfuss JM, Sehnem GD, Ressel LB, Teixeira CM. Percepções e vivências das mulheres acerca do climatério. Rev Enferm UFPE [Internet]. 2014 set; [cited 2018 dec 11]; 8(9):3039-46. Available from: https://periodicos.ufpe.br/revistas/revistaenfermagem/ article/view/10023https://doi.org/10.5205/reuol.5960-55386-1ED.0809201411

9. Minayo MCS. O desafio do conhecimento. Pesquisa qualitativa em saúde. In: $O$ desafio do conhecimento: pesquisa qualitativa em saúde. São Paulo: Hucitec; 2014.

10. Cabral IE. O método criativo e sensível: alternativa de pesquisa na enfermagem. In: Gauthier JHM, Cabral IE, Santos I, Tavares CMM Pesquisa em enfermagem: novas metodologias aplicadas. Rio de Janeiro: Guanabara Koogan; 1998. p.177-203.

11. Rodrigues DMMR, Labegalini CMG, Higarashi IH, Heidemann ITSB, Baldissera VDA. O percurso educativo dialógico como estratégia de cuidado em sexualidade com idosas. Esc Anna Nery [Internet]. 2015 [cited 2019 jan 05];22(3):e20170388. Available from: http://www.scielo. br/pdf/ean/v22n3/pt_1414-8145-ean-2177-9465-EAN-2017-0388. pdfhttp://dx.doi.org/10.1590/2177-9465-ean-2017-0388 
12. Tristão FR, Machado MP, Gracia OR, Lima DK. Vivências da mulher frente à histerectomia: aspectos emocionais. Revista Rede de Cuidados em Saúde [Internet]. 2017 jul; [cited 2018 nov 08]; 11(1):1-22. Available from: http://publicacoes.unigranrio.com.br/index.php/rcs/article/view/4379

13. Danesh M, Hamzehgardeshi Z, Moosazadeh M, Shabani-Asrami F. The effect of hysterectomy on women's sexual function: a narrative review. Med Arch [Internet]. 2015 dec; [cited 2018 dec 12]; 69(6):387392. Available from: https://www.ncbi.nlm.nih.gov/pmc/articles/ PMC4720466/. http://dx.doi.org/10.5455/medarh.2015.69.387-392

14. Lunelli BP, Bonfante TM, Locks GD, Giacomini DA, Fernandes CB. O impacto da histerectomia abdominal no desempenho/satisfação sexual. Arq Catarin Med [Internet]. 2014 jan/mar; [cited 2019 jan 13]; 43(1):4953. Available from: http://www.acm.org.br/revista/pdf/artigos/1272.pdf

15. Fram KM, Saleh SS, Sumrein IA. Sexuality after hysterectomy at University of Jordan Hospital: a teaching hospital experience. Arch Gynecol Obstet [Internet]. 2013 apr; [cited 2018 nov 15]; 287(4):703-8. Available from: https://link.springer.com/article/10.1007/s00404-0122601-2. http://dx.doi.org/10.1007/s00404-012-2601-2

16. Lonnée-Hoffmann R, Pinas I. Effects of Hysterectomy on Sexual Function. Curr Sex Health Rep [Internet]. 2014 dec; [cited 2018 dec 11] 6(4):244-51. Available from: https://link.springer.com/article/10.1007/ s11930-014-0029-3. http://dx.doi.org/10.1007/s11930-014-0029-3

17. Almeida F, Barbosa AM, Marques FJ, Heitmann PM, Neves VL. Leiomioma uterino: um estudo de caso que envolve o tratamento não conservador. Rev Eletrônica Gestão \& Saúde [Internet]. 2015 jun; [cited 2018 nov 05]; 6(Supl 3):2341-2359. Available from: https://dialnet. unirioja.es/descarga/articulo/5560290.pdf

18. Carvalho HC, Lemos MF. As Consequências da Histerectomia na Sexualidade Feminina. Perspect Psicol [Internet]. 2017 jun; [cited 2019 jan 10]; 21(1):1-10. Available from: http://www.seer.ufu.br/index.php/ perspectivasempsicologia/article/view/38934https://doi.org/10.14393/ PPv21n1a2017-13

19. Adorna E, Morari-Cassol E, Ferraz N. A Mastectomia e suas Repercussões na Vida Afetiva, Familiar e Social da Mulher. Rev Saúde (Santa Maria) [Internet]. 2017 jan/abr; [cited 2018 nov 17]; 43(1):1638. Available from: https://periodicos.ufsm.br/revistasaude/article/ view/23332http://dx.doi.org/10.5902/2236583423332

20. Wang X, Chen C, Liu P, Li W, Wang L, Liu Y. The morbidity of sexual dysfunction of 125 Chinese women following different types of radical hysterectomy for gynecological malignancies. Gynecol Obstet [Internet]. 2018 feb; [cited 2019 apr 25]; 297(2):459-466. Available from: https://link-springer-com.ez47.periodicos.capes.gov.br/content/ pdf/10.1007\%2Fs00404-017-4625-0.pdf
21. Berlit $S$, Tuschy B, Wuhrer A, Jürgens $S$, Buchweitz $O$, Kircher AT, et al. Sexual functioning after total versus subtotal laparoscopic hysterectomy. Arch Gynecol Obstet [Internet]. 2018 aug; [cited 2019 abr 25]; 298(2):337-344. Available from: https://link-springer-com.ez47. periodicos.capes.gov.br/content/pdf/10.1007\%2Fs00404-018-4812-7. pdf

22. Solbrække KN, Bondevik H. Absent organs - Present selves: exploring embodiment and gender identity in young Norwegian women's accounts of hysterectomy. Int J Qual Stud Health Well-being [Internet]. 2015 jan; [cited 2018 nov 21]; 10(26720):1-10. Available from: https://www.ncbi. nlm.nih.gov/pmc/articles/PMC4417683/http://dx.doi.org/10.3402/qhw. v10.26720

23. Santos JL, Cirqueira RP, de Albuquerque LS, Rodrigues TD, Ferreira JB. Função Sexual e Qualidade de Vida de Mulheres Submetidas à Histerectomia. Id on Line Rev Mult Psic [Internet]. 2018 jan; [cited 2018 nov 20]; 12(39):179-91. Available from: https://idonline.emnuvens.com. br/id/article/view/986https://doi.org/10.14295/idonline.v12i39.986

24. Pivetta HM, Braz MM, Real AA, Nascimento JR, Cabeleira ME, Veye AP. Disfunções do assoalho pélvico em pacientes submetidas à histerectomia: um estudo de revisão. Cinergis [Internet]. 2014 jan/mar [cited 2018 nov 12]; 15(1):48-52. Available from: http://online.unisc.br/ seer/index.php/cinergis/article/view/4638http://dx.doi.org/10.17058/ cinergis.v15i1.4638

25. Ferreira SMA, Gozzo TO, Panobianco MS, Santos MA, Almeida AM Barreiras na inclusão da sexualidade no cuidado de enfermagem de mulheres com câncer ginecológico e mamário: perspectiva das profissionais. Rev Latino-Am Enferm [Internet]. 2015 feb; [cited 2019 feb 06];23(1):82-9. Available from: http://www.scielo.br/pdf/rlae/v23n1/ pt 0104-1169-rlae-23-01-00082.pdfhttps://doi.org/10.1590/01041169.3602.2528

26. Illiano E, Giannitsas K, Zucchi A, Di Biase M, Del Zingaro M, Bini V et al. Sacrocolpopexy for posthysterectomy vaginal vault prolapse: long-term follow-up. Int Urogynecol J [Internet]. 2016 oct; [cited 2018 nov 17]; 27(10):1563-9. Available from: https://www.ncbi.nlm.nih.gov/ pubmed/26992724https://doi.org/10.1007/s00192-016-2998-4

27. Roudi O, Tirgari B, Cheraghi MA, Dehghan NN, Rayyani M. "Tender Care": Iranian Women's Needs to Cope with Hysterectomy and Oophorectomy - A Qualitative Content Analysis Study. International Journal of Community Based Nursing and Midwifery [Internet]. 2019 jan; [cited 2019 abr 26]; 7(1):63-74. Available from: https://www.ncbi. nlm.nih.gov/pmc/articles/PMC6311203/pdf/IJCBNM-7-63.pdf 